\title{
COMMUNITY STRUCTURE OF THE TINTINNIDS (CILIOPHORA: SPIROTRICHEA) IN THE REGION OF ABROLHOS (BAHIA, BRAZIL)
}

\author{
Alejandro Esteweson Santos Faustino da Costa ${ }^{1, *}$, Sigrid Neumann-Leitão ${ }^{1}$, Fabiano Lopes Thompson ${ }^{2}$, \\ Pedro Augusto Mendes de Castro Melo ${ }^{1}$ and Jana Ribeiro de Santana \\ ${ }^{1}$ Universidade Federal de Pernambuco, Centro de Tecnologia e Geociências \\ Museu de Oceanografia, Laboratório de Zooplâncton \\ (Av. Arquitetura s/n, 50740-550 Recife, PE, Brasil) \\ ${ }^{2}$ Universidade Federal do Rio de Janeiro \\ Instituto de Biologia \\ (Av. Carlos Chagas Filho, 373, 21941-902 Ilha do Fundão, RJ, Brasil) \\ *Corresponding Author: alejandroesteweson@hotmail.com
}

http://dx.doi.org/10.1590/S1679-87592015075206301

\begin{abstract}
A B S TR ACT
The tintinnid community in the region of Abrolhos (Bahia, Brazil) was studied during February 2012. We hypothesized that the tintinnid community structure varies significantly over a short temporal scale (photoperiod), as well as spatially over a short scale (on and away from the reefs), and a broad scale (distance of the reef area from the coast). Three areas in Abrolhos were studied. Two sampling points were delimited in each area, where the tintinnids were collected by horizontal subsurface plankton net (20 $\mu \mathrm{m}$ mesh-size) hauls. Sampling was undertaken every 6 hours, during 24 hours in each area. 24 species were found, all of which are of neritic, cosmopolitan, and of warm-water distribution. The only hypothesis that is not rejected is that related to variability on an extensive spatial scale. There are significant differences between the samples collected in the three areas studied (ANOVA $\mathrm{p}=0.017$ ). The clustering of the species highlights a continent-ocean gradient. There is one community typical of the internal arc, composed mainly of neritic agglutinated tintinnids, and another community typical of the external arc, composed mainly of hyaline warmwater and cosmopolitan tintinnids. The factor which exercises the greatest influence on the tintinnid community in the Abrolhos region is the distance from the coast.
\end{abstract}

\section{RESUMO}

A comunidade dos tintinídeos da região de Abrolhos (Bahia, Brasil) foi estudada durante o período de fevereiro de 2012. Nossas hipóteses são de que a estrutura da comunidade dos tintinídeos varia em uma escala temporal curta (fotoperíodo), além de variar espacialmente, tanto em curta escala (sobre o recife e distante dele) como em larga escala (distância da área recifal em relação à costa). Três áreas em Abrolhos foram estudadas. Em cada área foram delimitados dois pontos de amostragem, nos quais se coletou tintinídeos através de arrastos horizontais subsuperficiais de rede de plâncton $(20 \mu \mathrm{m}$ abertura de malha), a cada 6 horas, ao longo de 24 horas. 24 espécies foram encontradas, sendo todas de distribuição nerítica, cosmopolita e de águas quentes. A única hipótese não rejeitada está relacionada com a variabilidade da comunidade em uma escala espacial extensa. Existem diferenças significativas entre as três áreas estudadas (ANOVA $p=0,017$ ). Análises de agrupamento realizadas com as espécies revelaram um gradiente continente-oceano. Existe uma comunidade típica do arco interno, formada basicamente por espécies neríticas, além de uma comunidade típica do arco externo, formada basicamente por espécies hialinas cosmopolitas e de águas quentes. O grande fator influenciando a comunidade dos tintinídeos em Abrolhos é a distância da costa.

Descriptors: Protozooplankton, Ciliates, Coral reef ecosystems. Descritores: Protozooplâncton, Ciliados, Ecossistemas Recifais.

\section{INTRODUCTION}

Coral reefs are very highly diverse ecosystems, being second only in diversity to tropical forests (SOUTER and LINDÉN, 2000). Although these ecosystems occur in tropical regions, which are characterized by very low levels of dissolved nutrients, they present very high biomasses and 
production rates of many classes of organisms (LEWIS, 1977).

Since the 1970s, the importance of the bacteria in nutrient regeneration within reef ecosystems has been observed not only through the activity of the picoplankton, which are distributed in the water column, but also through the activity of those bacteria living in association with the mucusrich coral surface microlayer (SOROKIN, 1971; 1973; PAUL et al., 1986; FERRIER-PAGÈS and GATTUSO, 1998). The so-called microbial loop was described at the beginning of the 1980s (AZAM et al., 1983). According to this theory, picoplanktonic organisms constitute the main consumers of the dissolved organic carbon pool, using this material as an energy source for their growth. As they do so, part of this energy is reintroduced into the main food web through the feeding activity of protozooplanktonic organisms, mainly heterotrophic flagellates and ciliates (SHERR et al., 1989; BERNINGER and WICKHAM, 2005). These organisms serve as food sources for mesozooplanktonic and demersal organisms living in association with the coral reefs (STOECKER and CAPUZZO, 1990; FESSENDEN and COWLES, 1994; HEIDELBERG et al., 2004; CALBET and SAIZ, 2005). It is in this context that some microplanktonic protists, such as tintinnid ciliates, carry out a fundamental role within coral reef ecosystems. The tintinnids are a group of choreotrich ciliates that are characterized by the construction of a proteinaceous lorica (AGATHA and SIMON, 2012), inside which they dwell. The differences in lorica morphology are the main features used in tintinnid species identification. In addition to the importance of the tintinnids in connecting the microbial loop to the main food web, their intense feeding activity allows them to consume up to $70 \%$ of the daily primary production in some regions (BEERS and STEWART, 1971).

Because of their ecological importance in terms of nutrient regeneration, we studied the community structure of these ciliates in the region of Abrolhos. Three hypotheses were tested: i) the tintinnid community structure varies on a short temporal scale (photoperiod), since during the night period they may be exposed to a more intense predation rate as an effect of the feeding activity of mesozooplanktonic organisms (HEIDELBERG et al., 2004); ii) there is a significant difference between the community structure of the tintinnids on and away from the reefs, since the feeding activity specially of suspension-feeding benthonic organisms living in association with the reefs is responsible for a higher capture of planktonic organisms (GLYNN, 1973;
PRATAP et al., 1976; YAHEL et al., 1998); iii) the tintinnid community structure is significantly different in reef areas closer to and further from the coast as the availability of mineral particles, much more readily available in shallow areas, may interfere in the lorica building process, leading to a limitation of the spatial distribution of several species (GOLD and MORALES, 1976).

\section{Material and Methods}

Study Area

Situated off the southern littoral of the State of Bahia (northeastern Brazil), the region of Abrolhos consists of a complex of coral reefs, volcanic islands, mangrove forests, and tidal channels. A considerable part of this region lies within the protected National Marine Park of the Abrolhos, which covers approximately 270 square nautical miles (IBAMA, 1991).

Brazil is the only country bordering the western South Atlantic Ocean in which it is possible to find coral reefs (CASTRO and PIRES, 1999). The Abrolhos reefs constitute the most extensive and richest reefs in Brazilian waters (LEÃO, 2002). They are located on a wider area of the Brazilian continental shelf and are divided into two arcs. These arcs lie parallel to the coast, the internal one located closer to it than the external one, which is less extensive (IBAMA, 1991). The internal arc is located approximately $20 \mathrm{~km}$ from the coast, and the waters between this arc and the coast are up to $15 \mathrm{~m}$ deep. The Parcel das Paredes reef area is located in this arc. There is a channel between the two arcs with depths as great as $30 \mathrm{~m}$. The external arc is located approximately $70 \mathrm{~km}$ from the coast, and the depths are greater than $25 \mathrm{~m}$ (LEÃO, 2002). The Parcel dos Abrolhos reefs are located in this arc (see Fig. 1).

\section{Sampling Strategy and Analysis of the Samples}

The samples were collected in three different reef areas in the Abrolhos region: Parcel das Paredes (PP), Arquipélago de Abrolhos (AA), and Parcel dos Abrolhos (PA). In each area, two sampling sites were selected. One of them directly on the reef and identified as the reef site (R), while the other was located approximately $1 \mathrm{~km}$ from the reef and identified as the control site (C). 


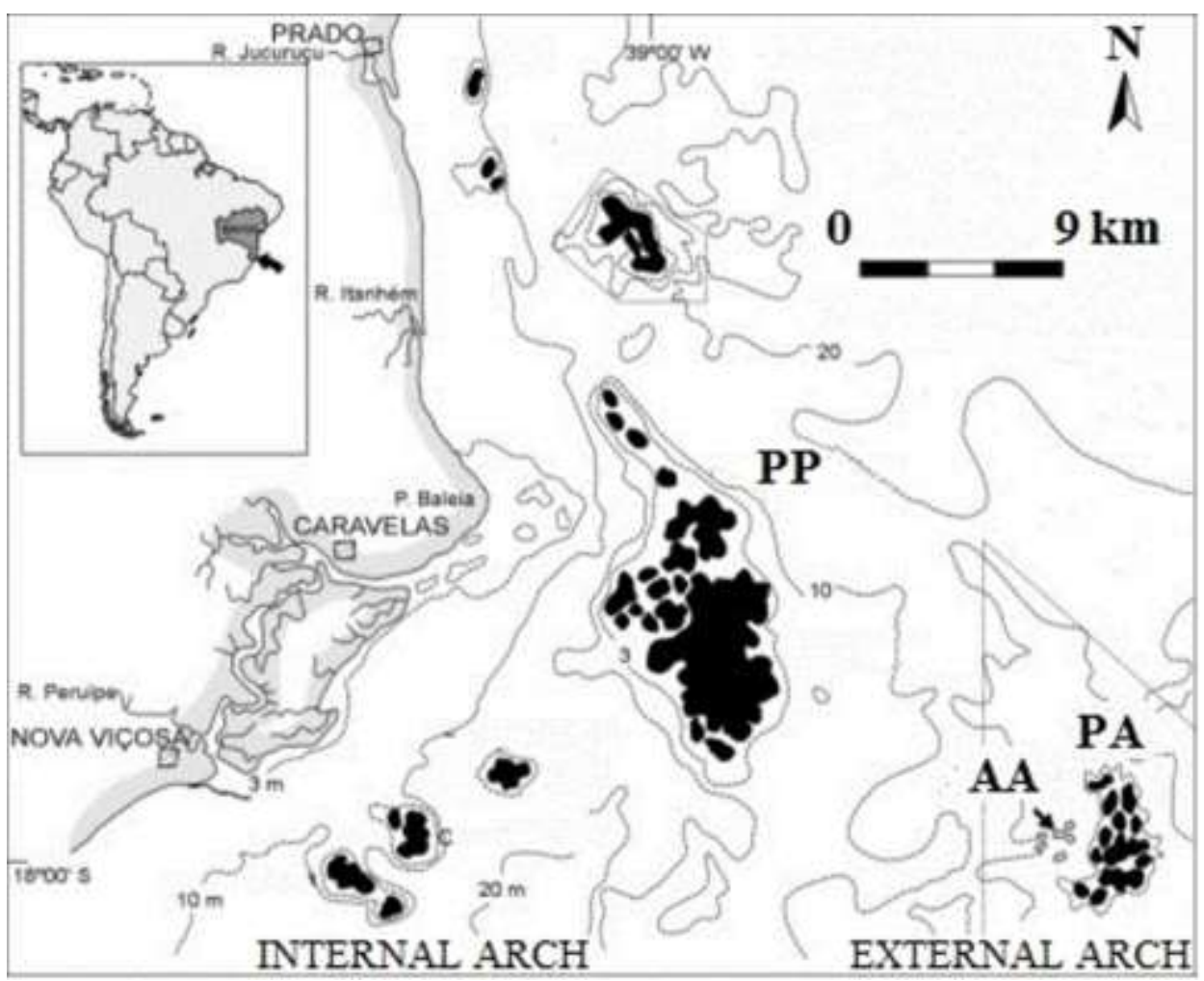

Fig. 1. Location of the Parcel das Paredes (PP), Arquipélago de Abrolhos (AA), and Parcel dos Abrolhos (PA) areas in the region of Abrolhos - BA, Brazil. Modified from LEÃO (2002).

Sampling was undertaken during a period of 24 hours in each area. The tintinnids were sampled by means of subsurface hauls with a plankton net (mesh width $20 \mu \mathrm{m}$, mouth diameter $30 \mathrm{~cm}$, length $2 \mathrm{~m}$ ). A flux meter was coupled to the mouth of the plankton net to assess the water volume filtered by the haul. The hauls were performed at 6-hour intervals at each site. A total of eight samplings were, thus, performed in each area, providing a total of 24 samples. All samples were fixed with borax-buffered formaldehyde at a final concentration of $4 \%$. This fixative may cause some level of shrinkage and distortion to ciliate cells (MODIGH and CASTALDO, 2005), but it does not affect tintinnid identification or quantitative estimates since the loricae used in such analyses are resistant and have been used historically (BRANDT, 1906; JÖRGENSEN, 1924; KOFOID and CAMPBELL, 1929).

Species identification was performed using classical and recent works on the taxonomy of the group (BRANDT, 1906; JÖRGENSEN, 1924; KOFOID AND CAMPBELL, 1929; HADA, 1937; CAMPBELL, 1942; BALECH, 1948; 1971; 1975; MARSHALL, 1969; FERNANDES, 2004a; 2004b; NOGUEIRA, 2002; 2005). The validity of the species' names was checked using the WoRMS digital data base (World Register of Marine Species: www.marinespecies.org). The quantitative analyses were performed using Sedgewick-Rafter chambers and common optical microscopy. During the procedure, a subsample $(1 \mathrm{ml})$ of the sample was taken to the Sedgewick-Rafter chamber, and all tintinnids contained in the subsample were identified and quantified. At least 100 individuals were counted in each subsample. The process was repeated three times for each sample, and the mean result of the three subsamples calculated. The mean values were used to calculate the tintinnid density (ind. $\mathrm{m}^{-3}$ ). The tintinnid biomass was calculated using the density values and biovolume of the loricae in accordance with the method proposed by HILLEBRAND et al. (1999). Mathematical equations were used to calculate the biovolume of the loricae $\left(\mu \mathrm{m}^{3}\right)$. The biovolume values were converted into biomass values $\left(\mathrm{pgC}^{-c e l l}{ }^{-1}\right)$ using a carbon to lorical biovolume ratio:

pgC.cell ${ }^{-1}=$ lorical biovolume $x 0.053+444.5$ (VERITY and LANGDON, 1984)

A cluster analysis was undertaken to determine the main species assemblages. The Ward method was used (ROMESBURG, 1984), using a 
similarity matrix produced by the determination of the Pearson linear correlation. Multidimensional scaling (MDS) was performed to visualize which samples were more closely related to each other.

A normality test was performed with the data to determine whether the results had a normal or non-normal distribution. It was necessary to evaluate whether there were significant differences between samples collected in different time periods (diurnal or nocturnal), between different points within the same area, or between different areas of the Abrolhos region, with the appropriate statistical tests. When the normality test pointed to a non-normal distribution of the results, non-parametric tests such as the KruskalWallis and Mann-Whitney tests were used to compare the results. When the normality test indicated a normal distribution of the results, parametric tests such as ANOVA and the t-test were used to compare the results.

\section{RESULTS}

Frequency of Occurrence, Relative Abundances, Quantitative and Biomass Results

The most conspicuous species were Codonellopsis schabii KOFOID and CAMPBELL (1929), Epiplocylis brandti KOFOID and CAMPBELL (1929), Tintinnopsis nana LOHMANN (1908), and T. beroidea STEIN (1867). The first two species were found to occur in $95 \%$ of the samples, while the latter two occurred in $73 \%$ (as shown in Table 1). Although these species presented high occurrence frequencies, they were more abundant in certain areas. C. schabii, for example, was more abundant in relation to the other species in the PP and AA areas. It represented $30 \%$ and $70 \%$, respectively, of the tintinnids found in these areas. In the PA area the relative abundance of the same species was only $2 \%$ (as shown in Table 1).

Table 1. Frequency of occurrence (FO), relative abundance (RA), mean density (MD), and mean biomass (MB) of the tintinnid species found in the PP, AA, and PA areas during February, 2012. The values of tintinnid mean density (Mean D.), tintinnid maximum density (Max. D.), tintinnid minimum density (Min. D.), tintinnid mean biomass (Mean B.), tintinnid maximum biomass (Max. B.), tintinnid minimum biomass (Min. B.), and standard deviation (SD) for each area during the diurnal and nocturnal periods, are also presented. Density values are presented in ind. $\mathrm{m}^{-3}$, and biomass values are presented in $\mu \mathrm{gC} . \mathrm{m}^{-3}$. The classification of the geographical distribution of each species is presented according to DOLAN and PIERCE (2013).

\begin{tabular}{|c|c|c|c|c|c|c|c|c|c|c|c|}
\hline & \multirow[b]{2}{*}{ Species } & \multicolumn{4}{|c|}{ Parcel das Paredes } & \multicolumn{2}{|c|}{ Arq. de Abrolhos } & \multicolumn{4}{|c|}{ Parcel Abrolhos } \\
\hline & & FO $(\%)$ & RA (\%) & MD & MB & RA (\%) & MD & MB & RA (\%) & MD & MB \\
\hline \multirow[t]{9}{*}{ Neritic } & Tintinnopsis fimbriata & 36 & 1.10 & 519 & 1.85 & 0.07 & 287 & 0.92 & - & - & - \\
\hline & Tintinnopsis gracilis & 36 & 6.94 & 2864 & 13.64 & - & - & - & - & - & - \\
\hline & Tintinnopsis beroidea & 73 & 0.61 & 672 & 0.91 & 37.12 & 19144 & 33.81 & 26.83 & 4004 & 8.34 \\
\hline & Tintinnopsis nana & 73 & 25.41 & 10481 & 11.67 & 1.71 & 1009 & 1.77 & 0.09 & 66 & 0.11 \\
\hline & Tintinnopsis tocantinensis & 9 & 0.04 & 64 & 0.08 & - & - & - & - & - & - \\
\hline & Tintinnopsis nucula & 5 & 0.02 & 56 & 0.22 & - & - & - & - & - & - \\
\hline & Favella cf. azorica & 14 & 0.10 & 112 & 1.77 & - & - & - & - & - & - \\
\hline & Leprotintinnus nordqvisti & 41 & 9.54 & 3938 & 37.97 & 0.02 & 96 & 0.65 & - & - & - \\
\hline & Metacylis mereschkowskii & 23 & 0.44 & 289 & 0.44 & - & - & - & - & - & - \\
\hline \multirow[t]{7}{*}{ Cosmopolitan } & Codonellopsis schabii & 95 & 30.27 & 12489 & 55.14 & 36.80 & 18978 & 76.56 & 2.10 & 313 & 1.11 \\
\hline & Codonellopsis ecaudata & 14 & - & - & - & 0.25 & 344 & 0.97 & - & - & - \\
\hline & Dadayiella ganymedes & 27 & 0.05 & 84 & 0.11 & 0.10 & 140 & 0.17 & 0.02 & 16 & 0.02 \\
\hline & Eutintinnus tubulosus & 64 & 13.66 & 7516 & 24.09 & 5.64 & 4651 & 13.30 & 25.39 & 6316 & 22.65 \\
\hline & Eutintinnus apertus & 36 & 5.83 & 6412 & 38.21 & 0.43 & 595 & 2.45 & 2.05 & 763 & 2.88 \\
\hline & Eutintinnus cf. pinguis & 23 & - & - & - & 1.03 & 2131 & 9.63 & 20.99 & 5221 & 26.09 \\
\hline & Ormosella sp. & 27 & 0.53 & 1761 & ND & 0.84 & 1156 & ND & 6.74 & 2516 & - \\
\hline \multirow[t]{15}{*}{ Warm-water } & Undella globosa & 45 & - & - & - & 1.50 & 1032 & 25.89 & 0.63 & 117 & 1.86 \\
\hline & Undella sp. & 64 & 0.32 & 210 & 2.92 & 1.64 & 846 & 11.75 & 0.09 & 66 & 0.92 \\
\hline & Rhabdonella elegans & 9 & 0.06 & 205 & 1.38 & - & - & - & 0.09 & 66 & 0.18 \\
\hline & Rhabdonella sp. & 5 & - & - & - & 0.07 & 305 & 0.73 & - & - & - \\
\hline & Ascampbelliella aperta & 5 & - & - & - & - & - & - & 0.19 & 138 & 0.61 \\
\hline & Epiplocylis brandti & 95 & 5.07 & 2093 & 10.38 & 12.14 & 6263 & 32.31 & 14.29 & 2132 & 11.53 \\
\hline & Epiplocylis cf. acuminata & 18 & - & - & - & 0.14 & 192 & 0.87 & 0.23 & 173 & 0.81 \\
\hline & Epiplocyloides reticulata & 41 & - & - & - & 0.48 & 332 & 1.29 & 0.29 & 72 & 0.26 \\
\hline & & Max. D. & Min. D. & Mean D. & SD & Max. B. & Min. B. & Mean B. & SD & & \\
\hline & PP Diurnal & 160559 & 5614 & 54388 & 71530 & 666.87 & 12.83 & 222.08 & 301.24 & & \\
\hline & PP Nocturnal & 32278 & 17714 & 28124 & 8100 & 148.52 & 84.06 & 110.25 & 29.38 & & \\
\hline & AA Diurnal & 81498 & 5229 & 46112 & 33040 & 321.52 & 13.83 & 170.76 & 129.17 & & \\
\hline & AA Nocturnal & 77021 & 34042 & 57034 & 18277 & 260.61 & 140.83 & 207.32 & 59.29 & & \\
\hline & PA Diurnal & 10392 & 257 & 3080 & 4893 & 39.98 & 2.39 & 12.29 & 18.47 & & \\
\hline & PA Nocturnal & 35108 & 27202 & 31155 & 5590 & 126.1 & 93.59 & 109.85 & 22.99 & & \\
\hline
\end{tabular}


The tintinnid density and biomass values were higher in the samples collected in the PP and AA areas than in the PA area (as shown in Table 1). In the first two areas, the tintinnids reached densities as high as 160,500 and 81,500 ind. $\mathrm{m}^{-3}$. Their highest biomass values in the PP and AA areas were 666.87 and 321.52 $\mu \mathrm{gC} . \mathrm{m}^{-3}$, respectively. In the PA area the highest density was 35,100 ind $\mathrm{m}^{-3}$, while the highest biomass was $126.1 \mu \mathrm{gC} . \mathrm{m}^{-3}$. The individual density values for each species in each sample are shown in Table 2, while the individual biomass values are shown in Table 3 .

\section{Temporal (Diurnal and Nocturnal Samples) and Spatial Variations}

There was no significant difference between the quantitative results for the diurnal and nocturnal samples collected in the PP and AA areas $(p>0.05)$. In the PA area, the diurnal and nocturnal samples were significantly different ( $t$-test $p=0.002$ ). The total density values were lower in the diurnal samples. There was no difference between the results of the samples collected at different points within the same area $(p>0.05)$. However, when the results obtained from the analysis of the samples collected in the three different areas were compared, the ANOVA indicated significant differences $(p=0.017)$.

\section{Cluster Analysis and MDS}

The cluster analysis provided two main groups of species association (see Fig. 2A). Group A consisted mainly of neritic species, whose distribution was limited to the PP area. Group B was further divided into two subgroups, one of which contained the widespread species, while the other contained the rare species. Both groups, however, contained mainly warm-water and cosmopolitan species (as shown in Table 1).

The multidimensional scaling (MDS) provided two main groups of samples, one containing the samples collected in the PP area (close to the coast), and other containing the samples collected in the PA and AA areas, thus highlighting a significantly different spatial distribution (Fig. 2B).

\section{Discussion}

Geographical Distribution and Biodiversity

PIERCE and TURNER (1993) described six different patterns of tintinnid global distribution using tintinnid occurrence data from more than 1,400 different locations worldwide. These distribution patterns were identified as cosmopolitan, neritic, warm-water, boreal, austral, and tropical Pacific. DOLAN and PIERCE (2013) updated these global distributions, increasing the number of sampled locations to more than 1,800 . The study excluded the tropical Pacific distribution, and some genera were moved from one distributional pattern to another. According to DOLAN and PIERCE (2013), the genera identified are classified as being of neritic, cosmopolitan and warm-water distributions (as shown in Table 1).

$A$

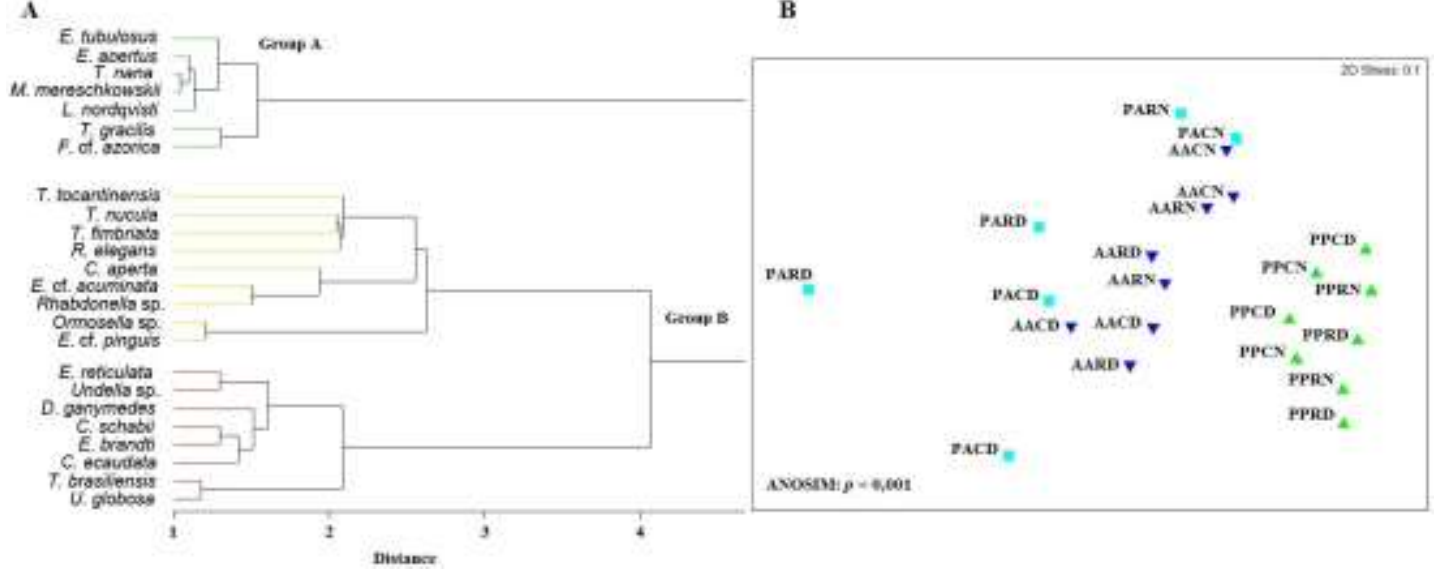

Fig. 2. Cluster analysis determining the most common species assemblages in the PP, AA, and PA areas during February, 2012. 2B - Multidimensional scaling (MDS) of the samples collected in the PP, AA, and PA areas during February, 2012. The $\mathrm{AA}$ and PA areas are more closely related to each other than to the PP area because they are located in the external reef arch. PP - Parcel das Paredes; AA - Arquipélago de Abrolhos; PA - Parcel dos Abrolhos; R - reef point; C - control point; D - diurnal period; $\mathrm{N}$ - nocturnal period. 
Table 2. Individual density values of each species in all the samples analyzed. All the samples were collected during February, 2012 in the Abrolhos region (Bahia, Brazil). The times at which the sampling was performed are indicated on the samples. Density values are presented in ind.m-3. PP - Parcel das Paredes; AA - Arquipélago de Abrolhos; PA - Parcel dos Abrolhos; R - Reef site; C - Control site.

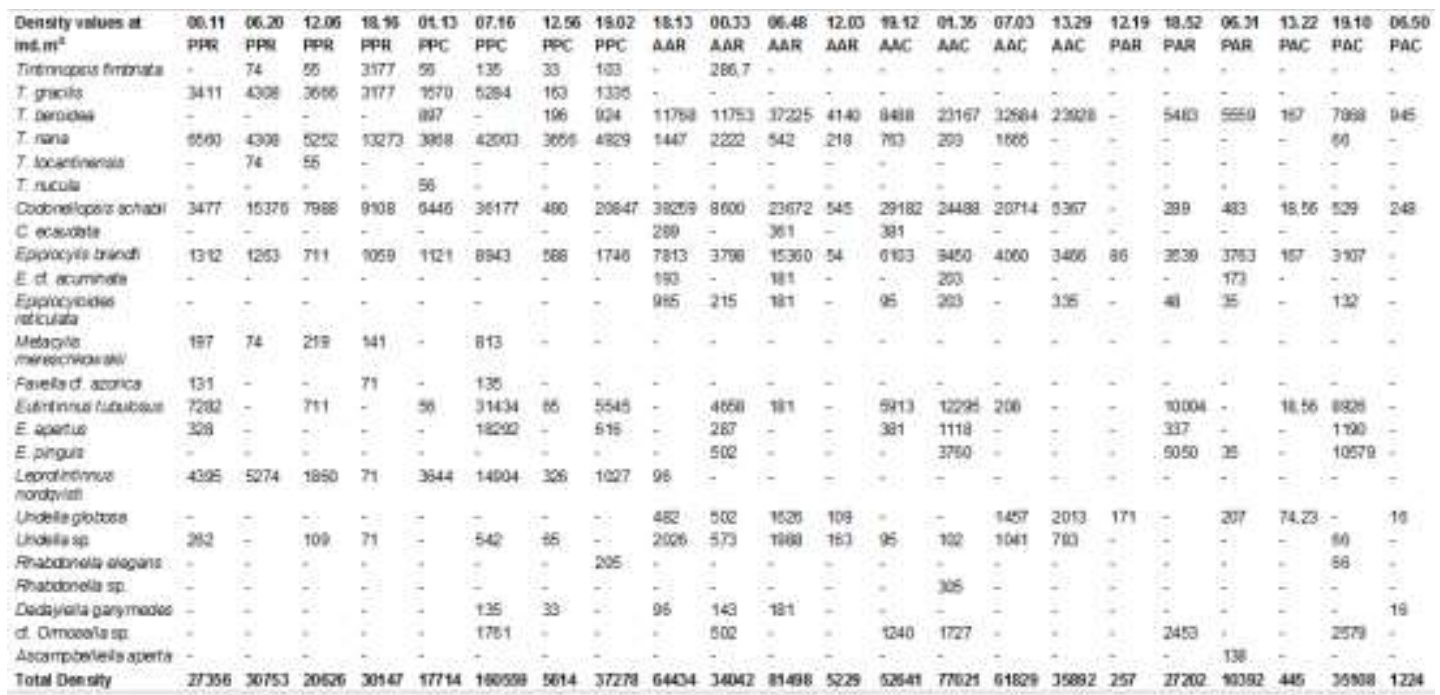

Table 3. Individual biomass values for each species in all the samples analyzed. All the samples were collected during February, 2012 in the Abrolhos region (Bahia, Brazil). The times at which the sampling was performed are indicated on the samples. Biomass values are presented in $\mu \mathrm{gC} . \mathrm{m}^{-3}$. PP - Parcel das Paredes; AA - Arquipélago de Abrolhos; PA - Parcel dos Abrolhos; $\mathrm{R}$ - Reef site; $\mathrm{C}$ - Control site.

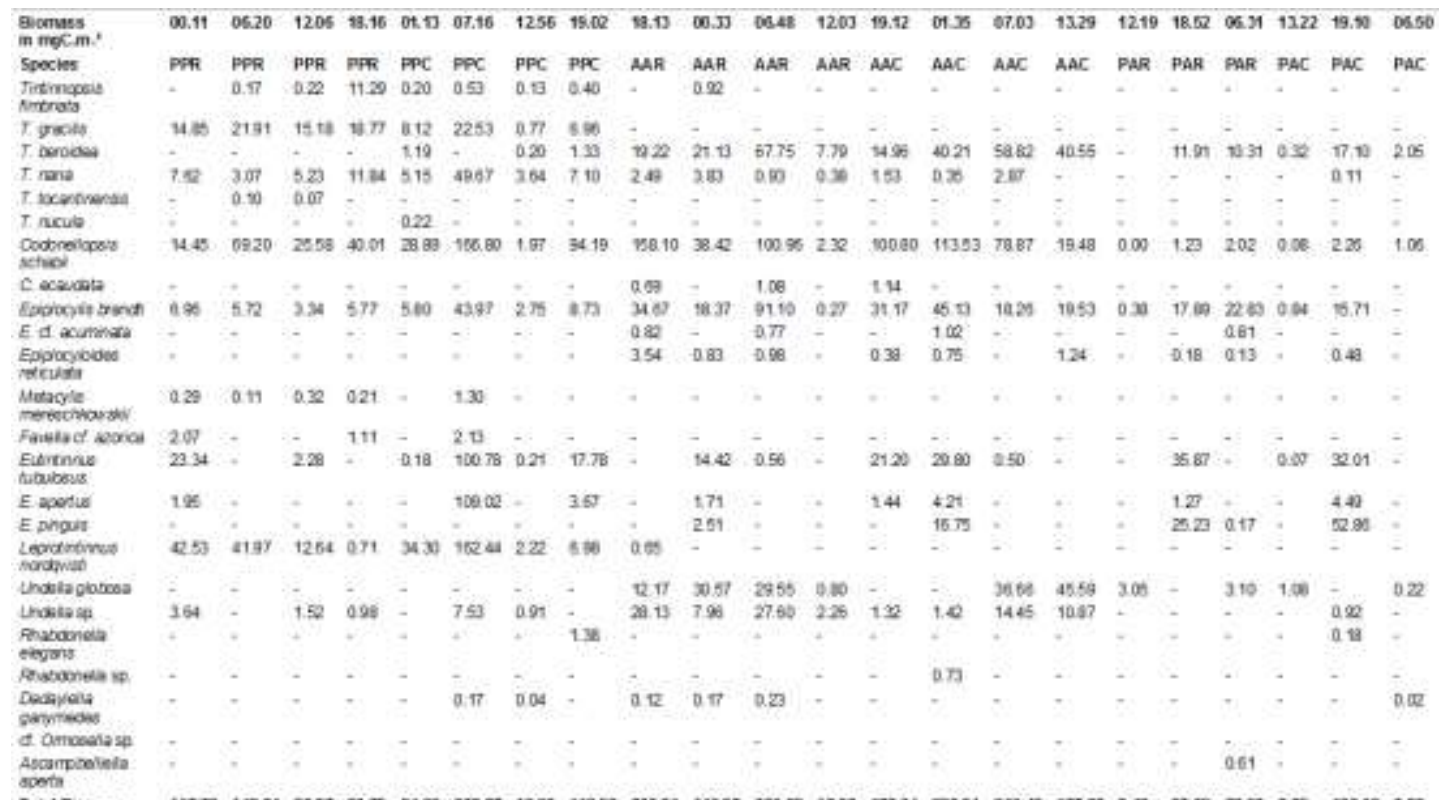

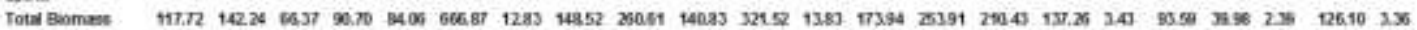


The neritic genus showed the highest number of species (9 species), despite the elevated number of warm-water genera ( 5 genera, as shown in Table 1). All species in the genera Tintinnopsis STEIN (1867) and Leprotintinnus JÖRGENSEN (1899) are known to incorporate mineral particles in their loricae. This could be a limiting factor to their distribution, restricting their occurrence to shallow water environments where such particles are readily available (PIERCE and TURNER, 1993). In environments where the availability of these particles is limited, the loricae produced by these agglutinated species are weaker (GOLD and MORALES, 1976). Interestingly, some tintinnid species may select specific types of particles (WASIK et al., 1996; GOLD and MORALES, 1976). These authors argue that some species are specific in their use of quartz, while others may select particles of biogenic origin, such as fragments of diatom frustules, protozoan shells and coccoliths. The study of the origin, shape, and size of the adhered particles may thus reveal information about the ecosystem in which the lorica was produced (RASSOULZADEGAN, 1980). The specificity in the selection of particles makes the agglutinated tintinnids an important means of mineral particle accumulation and transport to higher trophic levels in the food web (GOLD and MORALES, 1976).

Three of the four most conspicuous species in the study region are agglutinated tintinnids ( $C$. schabii, T. nana and T. beroidea). This finding arises from the fact that, although some of the areas studied are located far from the coast (because the AA and PA areas are situated in the external reef arc), these areas are characterized by shallow waters, which makes the ideal formation of agglutinated loricae possible. Thus, it is possible for agglutinated species to be part of the tintinnid community. In addition, the AA area is composed of five islands and fringe reefs (LEÃO, 2002). These islands may contribute the necessary particles for the ideal construction of agglutinated loricae. Even so, most of the agglutinated species occur exclusively or almost exclusively in the samples collected in the PP area, which is located in the internal arc, closer to the coast. These species are Tintinnopsis fimbriata MEUNIER (1919), T. gracilis KOFOID and CAMPBELL (1929), T. tocantinensis KOFOID and CAMPBELL (1929), T. nucula FOL (1884) and L. nordqvisti. Species of these genera are commonly found in coastal regions worldwide (BAKKER and PHAFF, 1976; PIERCE and TURNER, 1993; GODHANTARAMAN, 2002; DOLAN ET al., 2002; BOJANIC et al., 2012; DOLAN and GALLEGOS, 2001). Although they were quantitatively less abundant, some of these species, such as $T$. gracilis and L. nordqvisti, showed higher mean density values in the PP area than T. nana, which showed high mean density and was considered a conspicuous species in this area (as shown in Table 1).

The greater distance of the external arc from the coast influences the structure of the tintinnid community in the region. One of the most conspicuous species, E. brandti, in addition to 15 other species, builds hyaline loricae.

There are few studies on reef areas in Brazilian waters that mention the occurrence of tintinnids. MAYAL et al. (2009), NEUMANNLEITÃO et al. (2009) and MELO et al. (2002) found eight tintinnid species while studying the plankton of the Maracajaú reefs in the State of Rio Grande do Norte in the northeastern region of Brazil. Seven of these species had agglutinated loricae. The proximity of these reefs to the coastal region is the factor which most influences the dominance of species with agglutinated loricae in the community. SASSI and MELO (1982) studied the hyaline tintinnids on the Ponta do Seixas reefs in the State of Paraíba, also located in the northeastern region of Brazil. They collected samples weekly for two years and found only seven hyaline species. In addition, only two of these species presented a considerable occurrence frequency. Quantitative and biomass data are not presented in their study.

\section{Temporal-Spatial Variability}

Three hypotheses related to the temporalspatial variability in the tintinnid community were tested. The first hypothesis is related to the small-scale spatial variability. The hypothesis is the following: in each area of the study region, the tintinnid community found at the sites actually on the reefs is not the same as that found at sites further from them (control sites). This distribution may occur in response to the higher capture rate of planktonic organisms on the reefs, mainly by benthonic organisms living in association with the reefs, as has already been observed by several authors (GLYNN, 1973; PRATAP et al., 1976; YAHEL et al., 1998). This hypothesis was rejected. The community on the reefs is the same as that found at the control sites $1 \mathrm{~km}$ away from them. It is possible that the area under the influence of the reefs extends to these limits because no significant variations in quantitative terms, such as would support the limitation of the reef's influence, were observed.

The second hypothesis is related to the variability of the community over a broader spatial scale. The hypothesis consists of the idea that the tintinnid community found in the PP area is different from that found in the AA and PA areas. This difference would result from the fact that the PP area is located on the internal reef arc, much closer to the coast than the other two areas, which are located on the external reef arc, more than $50 \mathrm{~km}$ from the coast. 
This hypothesis was not rejected because significant differences were found between the results of the samples collected in the different areas (ANOVA $p=$ 0.017). The nature of the tintinnid community found in the PP area fits well with the pattern found in the Maracajaú reefs by MAYAL et al. (2009), NEUMANN-LEITÃO et al. (2009), and MELO et al. (2002). Studies performed in other coastal tropical areas show the same pattern of tintinnid composition with many agglutinated species (GODHANTARAMAN, 2002; JYOTHIBABU et al., 2006). In the PP, a great number of agglutinated species were found, although a considerable number of hyaline species were also identified, similarly to the findings of SASSI and MELO (1982) on the Ponta do Seixas reefs. Farther from the coast, in the AA and PA areas, the number of agglutinated species decreased, whereas the number of hyaline species increased. This continent-ocean gradient is highlighted by multidimensional scaling (MDS). It is possible to clearly visualize how the samples collected in the internal arc, in the PP area, assembled separately from the samples collected in the external reef arc, in the $\mathrm{AA}$ and PA areas (see Figure 2B). The species assemblages are also a result of the continent-ocean gradient (see Figure 2A).

The third hypothesis tested is related to possible variations in the tintinnid community between the diurnal and nocturnal periods. The hypothesis is that the total tintinnid density and biomass are significantly different as between the diurnal and nocturnal periods, mainly due to differential predation as the nocturnal feeding activity of mesozooplanktonic demersal organisms could lead to a decrease in the density of microplanktonic organisms (HEIDELBERG et al., 2004). Statistical tests were performed separately for each area, and differences were only found in the PA area (t-test $p=0.002)$. The most plausible explanation is that this result is a misleading statistical artifact because the nocturnal values, although higher than the diurnal values in this area, are lower than the mean density values found in other areas during both the diurnal and nocturnal periods (as shown in Table 1). ZEITSCHEL (1969) argued that there was no variation in the vertical distribution of tintinnids between the diurnal and nocturnal periods. NOGUEIRA and SASSI (2011) studied the nycthemeral variation of the tintinnid community in the region of the Atol das Rocas in the northeastern region of Brazil. They found higher values of tintinnid densities during the nocturnal period but interpreted this result as a spurious observation.

Density and Biomass

Although MELO et al. (2002), MAYAL et al. (2009), and NEUMANN-LEITÃO et al. (2009) present no specific quantitative data for tintinnid ciliates, they do present quantitative data for the entire microzooplankton community, which varied between 1,917 and 47,620 ind. $\mathrm{m}^{-3}$. The total density values for the tintinnid community in the Abrolhos region varied between 257 and 160,559 ind. $\mathrm{m}^{-3}$ (as shown in Table 1), which highlights the importance of these ciliates in the ecosystem. The tintinnids alone reached very high density values in some samples, and their mean density values in each area were close to the highest density values found in the Maracajaú reef system for the entire microzooplanktonic community. Although the tintinnid biomass values were lower than the microzooplanktonic biomass values found by other authors in reef systems (MELO ET AL., 2002; MAYAL et al., 2009; NEUMANN-LEITÃO et al., 2009), the tintinnids play a very important role in energy transfer within these ecosystems. They are characterized by intense feeding activity, being able to consume up to $70 \%$ of the daily primary production (BEERS and STEWART, 1971), and their feeding activity is sometimes similar to that of copepods (CAPRIULO and CARPENTER, 1980; CAPRIULO and CARPENTER, 1983). In addition, tintinnids serve as a direct food source for benthonic organisms living in association with coral reefs because they represent part of the microplanktonic community (GLYNN, 1973; PRATAP et al., 1976; YAHEL et al., 1998; DUPUY et al., 1999; HEIDELBERG et al., 2004). Tintinnids may also serve as an indirect food source for benthic taxa because they constitute an important food item for mesozooplanktonic organisms (GIFFORD and DAGG, 1988; SANDERS and WICKHAM, 1993; DOLAN and GALLEGOS, 2001). In this way, the measurement of the biomass is a specific datum; the tintinnid biomass levels may remain low, even though they may present very high secondary production because their life cycle is much shorter than that of most other zooplanktonic organisms, with estimates of up to 1.2 generations per day (DOLAN, 2010).

In conclusion, there is no variation in the tintinnid community structure on a short spatial scale in the Abrolhos region, and this hypothesis is therefore rejected. In contrast, on a broader spatial scale, the existence of variation in the tintinnid community was not rejected. There is one community typical of the internal arc closer to the coast, composed mainly of agglutinated tintinnids of neritic distribution, and another community typical of the external arc, which is composed mainly of hyaline tintinnids of broader distribution (warm-water and cosmopolitan species). The continent-ocean gradient was also highlighted by the species' assemblages. The hypothesis of variation in the tintinnid community over a short timescale (diurnal and nocturnal periods) was also rejected. The factor which most influences the tintinnid community 
structure in the Abrolhos region is the distance of the reefs from the coast.

\section{ACKNOWLEDGMENTS}

We would like to express our thanks to Professors Tâmara de Almeida e Silva (Bahia State University, UNEB), Ralf Schwamborn (Federal University of Pernambuco, UFPE) and Fernando de F. Porto Neto (Rural Federal University of Pernambuco, UFRPE) for their significant comments on the manuscript before its submission, as well as to professor Rodrigo Leão de Moura (Federal University of Rio de Janeiro, UFRJ) for his important contribution to the sampling plan and the logistics of the field work. We would also thank the CNPq (PROABROLHOS) for their financial support. This paper is a contribution of the Rede Abrolhos (Abrolhos Network - www.abrolhos.org), funded by $\mathrm{CNPq} / \mathrm{CAPES} / \mathrm{FAPES} / \mathrm{FAPERJ}$ (Programs SISBIOTA and PELD).

\section{REFERENCES}

AGATHA, S. and SIMON, P. On the nature of tintinnid loricae (Ciliophora: Spirotricha: Tintinnina): a histochemical, enzymatic, EDX, and high-resolution TEM study. Acta Protoz., 51: 1 - 19. 2012.

AZAM, F.; FENCHEL, T.; FIELD, J. G.; GRAY, J. S.; MEYER-REIL, L. A. and THINGSTAD, F. The ecological role of water-column microbes in the sea. Mar. Ecol. Prog. Ser., 10: 257 - 263. 1983.

BAKKER, C. and PHAFF, W. J. Tintinnida from coastal waters of the S.W.-Netherlands I. The genus Tintinnopsis Stein. Hydrobiol., 50: 101 - 111. 1976.

BALECH, E. Tintinnoinea de Atlantida. Comunicaciones del Museo Argentino de Ciencias Naturales "Bernardino Rivadavia" Serie Ciencias Zoologicas num. 7. 1948.

BALECH, E. Microplancton del Atlantico Ecuatorial Oeste (Equalant I). Servicio de Hidrografia Naval, H 654: 1 103. 1971.

BALECH, E. La família Undellidae (Protozoa, Ciliophora, Tintinnina). Physis, sección A, 34(89):377-398. 1975.

BEERS, J. R. and STEWART, G. L. Micro-zooplankters in the plankton communities of the upper waters of the Eastern Tropical Pacific. Deep Sea Res., 18: $861-883$. 1971.

BERNINGER, U. G. and WICKHAM, S. A. Response of the microbial food web to manipulation of nutrients and grazers in the oligotrophic Gulf of Aqaba and northern Red Sea. Mar. Biol., 147: 1017 - 1032. 2005.

BOJANIC, N.; OLJAVIDJAC; SOLIC, M.; KRSTULOVIC, N.; BRAUTOVIC, I.; MATIJEVIC, S.; KUSPILIC, G.; SESTANOVIC, S.; GLADAN, Z. N. and MARASOVIC, I. Community structure and seasonal dynamics of tintinnid ciliates in Kastela Bay (middle Adriatic Sea). J. Plankt. Res., 34(6):510-530. 2012.
BRANDT, K. Die Tintinnodeen der Plankton-Expedition. Ergebnisse der Plankton-Expedition der HumboldtStiftung. Bd III, L. a. 1906.

CALBET, A. and SAIZ, E. The ciliate-copepode link in marine ecosystems. Aquat. Microb. Ecol., 38: 157 167. 2005.

CAPRIULO, G. M. and CARPENTER, E. J. Grazing by 35 to $202 \mu \mathrm{m}$ micro-zooplankton in Long Island Sound. Mar. Biol., 56: 319 - 326. 1980.

CAPRIULO, G. M. and CARPENTER, E. J. Abundance, species composition and feeding impact of tintinnid micro-zooplankton in Central Long Island Sound. Mar. Ecol. Prog. Ser., 10: 277 - 288. 1983.

CAMPBELL, A. S. The oceanic Tintinnoinea of the plankton gathered during the last cruise of the Carnegie. Scientific results of cruise VII of the Carnegie during 1928-1929 under command of Captain J. P. Ault, Carnegie Institution of Washington Publication 537. 1942.

CASTRO, C. B. and PIRES, D. O. A bleaching event on a Brazilian coral reef. Rev. bras. Oceanogr., 47(1): 87 90. 1999

DOLAN, J. R. and GALLEGOS, C. L. Estuarine diversity of tintinnids (planktonic ciliates). J. Plankt. Res., 23(9): 1009 - 1027. 2001.

DOLAN, J. R.; CLAUSTRE, H.; CARLOTTI, F.; PLOUNEVEZ, S. and MOUTIN, T. Microzooplankton diversity: relationships of tintinnid ciliates with resources, competitors and predators from the Atlantic Coast of Morocco to the Eastern Mediterranean. Deep Sea Res. I, 49: 1217 - 1232. 2002.

DOLAN, J. R. Morphology and ecology in tintinnid ciliates of the marine plankton: correlates of lorica dimensions. Acta Protoz., 49: 235 - 244. 2010.

DOLAN, J. and PIERCE, R. W. Diversity and distributions of tintinnids. In: DOLAN, J. R.; MONTAGNES, D. J. S.; AGATHA, S.; COATS, D. W. and STOECKER, D. $\mathrm{K}$. (Eds). The biology and ecology of tintinnids ciliates: models for marine plankton. WilleyBlackwell. 2013. Chapter 10: 214 - 243.

DUPUY, C.; GALL, S. L.; HARTMANN, H. J. and BRÉRET, M. Retention of ciliates and flagellates by the oyster Crassostrea gigas in French Atlantic coastal ponds: protists as a trophic link between bacterioplankton and benthic suspension feeders. Mar. Ecol. Prog. Ser.177: 165 - 175. 1999.

FERNANDES, L. F. Tintininos (Ciliophora, Tintinnina) de águas subtropicais na região Sueste-Sul do Brasil. I. Familias Codonellidae, Codonellopsidae, Coxliellida, Cyttarocylidae, Epiplocylidae, Petalotrichidae, Ptychocylidae, Tintinnididae e Undellidae. Rev. bras. Zool., 21 (3): 551 - 576. 2004a.

FERNANDES, L. F. Tintininos (Ciliophora, Tintinnina) de águas subtropicais na região Sudeste-Sul do Brasil. II. Familias Dictyocistidae, Rhabdonellidae, Tintinnidae e Xystonellidae. Rev. bras. Zool., 21 (3): 605 - 628. 2004b.

FERRIER-PAGÈS, C. and GATTUSO, J. -P. Biomass, production and grazing rates of picoplankton and nanoplankton in coral reef waters (Miyako Island, Japan). Microb. Ecol., 35: 46 - 57. 1998.

FESSENDEN, L. and COWLES, T. J. Copepod predation on phagotrophic ciliates in Oregon coastal waters. Mar. Ecol. Prog. Ser.107: 103 - 111. 1994. 
GIFFORD, D. J. and DAGG, M. J. Feeding of the estuarine copepod Acartia tonsa Dana: carnivory vs. herbivory in natural microplankton assemblages. Bull. Mar. Sci., 43(3): $458-468.1988$.

GLYNN, P. W. Ecology of a Caribbean coral reef. The Porites reef-flat biotope: Part II. Plankton community with evidence for depletion. Mar. Biol., 22: $1-21$. 1973.

GODHANTARAMAN, N. Seasonal variations in species composition, abundance, biomass, and estimated production rates of tintinnids at tropical estuarine and mangrove waters, Parangipettai, southeast coast of India. Mar. Ecol. Prog. Ser., 166: 83 - 97. 2002.

GOLD, K. and MORALES, E. A. Studies on the sizes, shapes, and the development of the lorica of agglutinated Tintinnida. Biol. Bull., 150: 377 - 392. 1976.

HADA, Y. The fauna of Akkeshi Bay: IV. The pelagic Ciliata. Jour. Fac. Sci., Hokkaido Univ., Ser. VI, Zool. 6, 5(3): 143 - 216. 1937.

HADA, Y. Studies on the Tintinnoinea from the Western Tropical Pacific. Jour. Fac. Sci., Hokkaido Univ., Ser. VI, Zool. 6, 87-190. 1938.

HEIDELBERG, K. B.; SEBENS, K. P. and PURCELL, J. E. Composition and sources of near reef zooplankton on a Jamaican forereef along with implications for coral feeding. Coral Reefs, 23: 263 - 276. 2004.

HILLEBRAND, H.; DÜRSELEN, C - D.; KIRSCHEL, D.; POLLINGHER, $\mathrm{U}$. and ZOHARY, T. Biovolume calculation for pelagic and benthic microalgae. J. Phycol., 35: 403 - 424. 1999.

IBAMA. Instituto Brasileiro do Meio Ambiente e dos Recursos Naturais Renováveis/Fundação Pró-Natureza. Plano de Manejo: Parque Nacional Marinho dos Abrolhos/IBAMA FUNATURA. Brasília; Aracruz Celulose S.A., 1991.96 p.

JÖRGENSEN, E. Mediterranean Tintinnidae. Report on the Danish oceanographical expeditions 1908-10 to the Mediterranean and adjacent Seas, Vol II, Biology. Copenhagen, Andr. Fred. Høst and Søn. 1924.

JYOTHIBABU, R.; MADHU, N. V.; JAYALAKSHMI, K. V.; BALACHANDRAN, K. K.; SHIYAS, C. A.; MARTIN, G. D. and NAIR, K. K. C. Impact of freshwater influx on microzooplankton mediated food web in a tropical estuary (Cochin backwaters and India). Estuar. Coast. Shelf Sci., 69: 505 - 518. 2006.

KOFOID, C. A. and CAMPBELL, A. S. A conspectus of the marine and freshwater Ciliata belonging to the suborder Tinntinoinea, with descriptions of new species principally from the Agassiz Expedition to the Eastern Tropical Pacific 1904 - 1905. UC Publ. Zool., 34: 1 403. 1929.

LEÃO, Z. M. A. N. Abrolhos, BA - O complexo recifal mais extenso do Atlântico Sul. In: Schobbenhaus, C.; Campos, D. A.; Queiroz, E. T.; Winge, M.; Berbert-Born, M. L. C. (Editores). Sítios Geológicos e Paleontológicos do Brasil. Brasilia: DNPM/CPRM - Comissão Brasileira de Sítios Geológicos e Paleobiológicos (SIGEP), 1: 345 359. 2002.

LEWIS, J. B. Processes of organic production on coral reefs. Biol. Rev., 52(3): 305 - 347. 1977.

MARSHALL, S. M. Protozoa: Order Tintinnida. Conseil international pour l'exploration de la mer, zooplankton sheet 117. 1969.
MAYAL, E. M.; LEITÃO, S. N.; FEITOSA, F. A. N.; SCHWAMBORN, R.; SILVA, T. A. and SILVACUNHA, M. G. G. Hydrology, plankton, and corals of the Maracajaú reefs (Northeastern Brazil) - an ecosystem under severe thermal stress. Braz. Arch. Biol. Techn.: An International Journal, 52(3): 665 - 678. 2009.

MELO, N. F. A. C.; LEITÃO, S. N.; SILVA, T. A.; SCHWAMBORN, R. and GUSMÃO, L. M. de A. Zooplankton from the Maracajaú Reefs, Northeastern Brazil. Trop. Oceanogr., 30(2): 133 - 145. 2002.

MODIGH, M. and CASTALDO, S. Effects of fixatives on ciliates as related to cell size. J. Plankt. Res., 27(8): 845 - 849. 2005.

NEUMANN - LEITÃO, S.; FEITOSA, F. A. N.; MAYAL, E.; SCHWAMBORN, R.; SILVA-CUNHA, M. G. G.; SILVA, T. A.; MELO, N. F. and PORTO NETO, F. F. The plankton from Maracajaú reef ecosystem (Brazil) offshore coral reefs under multiple human stressors. WIT Trans. Ecol. Environ., 122: 173 - 182. 2009.

NOGUEIRA, E. M. S.; SASSI, R. and LIRA, M. C. A. A família Tintinnidae (Claparède and Lachmann, 1858) (Ciliophora-Oligotrichida) do Atol das Rocas (RN) e Fernando de Noronha (PE), Brasil. Trop. Oceanogr., 30 (2): 105 - 118. 2002.

NOGUEIRA, E. M. S.; SASSI, R. and CORDEIRO, T. A. The Rhabdonellidae (Tintinnina: Oligotrichida) from Atol das Rocas and Fernando de Noronhha Archipelago, Southwestern Atlantic, Brazil. Arq. Ciênc. Mar., 38: 93 $-104.2005$.

NOGUEIRA, E. M. S. and SASSI, R. Nychthemeral variations of Tintinnina (Ciliata : Oligotrichida) near the Rocas atoll (South Atlantic) and relationships with other microzooplanktonic components. Arq. Ciênc. Mar., 44(1): 5 - 11. 2011.

PAUL, J. H.; DEFLAUN, M. F. and JEFFREY, W. H. Elevated levels of microbial activity in the coral surface microlayer. Mar. Ecol. Prog. Ser., 33: 29 - 40. 1986.

PIERCE, R. W. and TURNER, J. T. Global biogeography of marine tintinnids. Mar. Ecol. Prog. Ser., 94: $11-26$. 1993.

PRATAP, M. M.; WAFAR, M. V. M.; HARIDAS, P.; NARAYANAN, B.; MENON, P. G. and SIVADAS, P. Comparative studies on the abundance of zooplankton in the surrounding sea and lagoons in the Lakshadweep. Indian J. Mar Sci., 6: 138 - 141. 1976.

RASSOULZADEGAN, F. Granulometric analysis of the particles used by a tintinnid Stenosemella ventricosa (Clap. and Lachm.) Jorg., during lorica building. Protistologica, 16: 507 - 510. 1980.

ROMESBURG, H. C. Cluster analysis for researchers. USA: Wadsworth, 1984. 335 p.

SANDERS, R. W. and WICKHAM, S. A. Planktonic protozoa and metazoa: predation, food quality and population control. Mar. Microb. Food Webs, 7(2): 197 -223. 1993.

SASSI, R. and MELO, G. N. Contribuição ao conhecimento da fauna de protozoários do estuário do Rio Paraíba do Norte. Tintinoideos do Rio Mandacarú. Rev. Nordestina Biol., 5(2): $14-155.1982$.

SHERR, E. B.; RASSOULZADEGAN, F.; and SHERR, B. F. Bacterivory by pelagic choreotrichous ciliates in coastal waters of the NW Mediterranean Sea. Mar. Ecol. Prog. Ser., 55: 235 - 240. 1989. 
SOROKIN, Y. I. On the role of bacteria in the productivity of tropical oceanic waters. Internationale Revue der gesamten Hydrobiologie und Hydrographie, 56: 1 48. 1971.

SOROKIN, Y. I. Trophical role of bacteria in the ecosystem of the coral reef. Nature, 242: $415-417.1973$.

SOUTER, D. W. and LINDÉN, O. The health and future of coral reef systems. Ocean coast. Manag., 43: $657-688$. 2000.

STOECKER, D. K. and CAPUZZO, J. McD. Predation on protozoa: its importance to zooplankton. J. Plankt. Res., 12(5):891-908. 1990.

VERITY, P. G. and LANGDON, C. Relationships between lorica volume, carbon, nitrogen, and ATP content of tintinnids in Narragansett Bay. J. Plankt. Res., 6(5):859-868. 1984.

WASIK, A.; MIKOLAJCZYK, E. and LIGOWSKI, R. Agglutinated loricae of some Baltic and Antarctic Tintinnina species (Ciliophora). J. Plankt. Res., 18(10):1931-1940. 1996.
YAHEL, G.; POST, A. F.; FABRICIUS, K.; MARIE, D.; VAULOT, D. and GENIN, A. Phytoplankton distribution and grazing near coral reefs. Limnol. Oceanogr., 43(4):551-563. 1998.

ZEITSCHEL, B. Tintinnen dês westlichen Arabischen Meeres, ihre Bedeutung als Indikatoren für Wasserkörper und Glied der Nahrungskette. Meteor Forsch. Ergebnisse., D(4): 47 - 101. 1969.

(Manuscript received 20 January 2014; revised 25 October 2014; accepted 31 October 2014) 